ROCZNIKI NAUK SPOŁECZNYCH

Tom 11(47), numer $2 \quad-\quad 2019$

DOI: http://dx.doi.org/10.18290/rns.2019.47.2-3

\title{
JACEK WYSOCKI
}

\section{CREATION OF ECOLOGICAL COMPETENCES WITHIN A COMPANY - A THEORETICAL APPROACH}

\section{INTRODUCTION}

In post-industrial economy based on knowledge and new technologies, characterised by the increasing significance of both social and ecological corporate responsibility, the possession of a set of defined competences particularly in the environmentally friendly area of operation is a condition for the successful growth of companies. Ecological competences, also known as green competences, similarly to ecological products, technologies and innovations, have long constituted an effective source of competitive edge that increases both the value of companies and their market success. This fact is partially connected with the growing popularity of the ecological approach to business worldwide and partially with the perception of environmental issues in terms of stimulating corporate growth since ecological threats provide an opportunity to propagate environmentally friendly solutions. Green knowledge and competences, when present in companies, can effectively prevent the occurrence of environmental problems and properly shape environmental security, which is associated with the elimination of ecological threats not only at the macro or mezzo scale but also at the micro scale. ${ }^{1}$ Consequently, these competences may potentially prove to be the key condition for success determining the company's competitive advantage - hence

JACEK WysOCKI, PhD Hab, Institute of Enterprise, Collegium of Business Administration, SGH Warsaw School of Economics; address for correspondence: Al. Niepodległości 162, 02-554 Warsaw, Poland; e-mail: jwysoc@sgh.waw.pl; https://orcid.org/0000-0003-3815-8500.

${ }^{1}$ A. ChODYŃSKI, "Bezpieczeństwo ekologiczne, kompetencje a zaufanie międzyorganizacyjne. Aspekty strategiczne," in Społeczne i ekologiczne aspekty zarzadzania, ed. Andrzej Chodyński (Kraków: Krakowskie Towarzystwo Edukacyjne - Oficyna Wydawnicza AFM, 2007), 193-99. 
the author's decision to devote the presented article to the theoretical aspect of these competences.

\section{THE CONCEPT OF COMPETENCE IN ECONOMIC LITERATURE}

Contemporary concepts describing the notion of competences in the aspect of company management organise and comprehensively define all of the major issues related to the influence of competences on the functioning, market value and further growth of an organisation, hence further research on the nature of this phenomenon is definitely recommended. In compliance with the resource concepts, related to the internal competitiveness factors, competences constitute specific resources enabling the company to "do something" better than their competitors in all areas of their business activity. ${ }^{2}$ Therefore, these competences become a manifestation of the integration of both tangible and intangible assets into one compatible whole capable of generation of practical value which will be perceived by customers as more attractive than the offer of their competitors. ${ }^{3}$

Generally, competences determine the company's ability to use all of its production capabilities related to the resources at its disposal, ${ }^{4}$ and this ability to perform specific activities makes it possible to build competences only under certain conditions - when it is possible to add the phrase being able to do something means doing it to the phrases knowing how to do something and being able to do something. ${ }^{5}$ On the other hand, a more analytic approach treats competences as the effect of a whole made up by the three elements listed below: ${ }^{6}$

\footnotetext{
${ }^{2}$ Resource competences result from the development of "the school of resources, abilities and learning." However, it is assumed that Edith Penrose introduced the concept of competence in literature. E. Penrose, The Theory of Growth of the Firm, Resources, Firms and Strategies (Oxford: Oxford University Press, 1997), 54.

${ }^{3}$ E. URbanowska-SoJkin, P. BANASZYK, and H. WitcZAK, Zarzadzanie strategiczne przedsiębiorstwem (Warsaw: PWE, 2004), 230.

${ }^{4}$ In the literature on the subject abilities are sometimes identified with skills and even more frequently they are considered to be an element of skills. M. J. STANKIEwicz, Konkurencyjność przedsiębiorstw. Budowanie konkurencyjności przedsiębiorstwa $w$ warunkach globalizacji (Toruń: „Dom Organizatora”, 2002), 101-3.

${ }^{5}$ J. RoKITA, Zarzadzanie strategiczne. Tworzenie i utrzymanie przewagi konkurencyjnej (Warsaw: PWE, 2005), 144.

${ }^{6}$ B. de Wit and R. Meyer, Strategy: Process, Content, Context, An International Perspective (London: International Thomson Business Press, 1998), 337.
} 
- knowledge, which is the basis of an efficient and effective operation of the company,

- abilities, which constitute the company's potential required to conduct specific activities and to organise them into systems of activities,

- attitudes, which constitute a reflection on the views represented within the company (willingness and predispositions to specific activities).

Competences analysed in this manner prove complementary in relation to the company's resources and they jointly constitute the medium of the company's competitive advantage, and the element serving to combine these elements into a unit is the employees and their knowledge. ${ }^{7}$ At the same time, we can see a division between the concept of resources that support production processes and are basic units of analysis requiring accumulation and coordination, and the concept of competences that occur at a higher level of aggregation and refer to the ability of a group of resources in case of proper management of realisation of tasks intended to achieve targets. ${ }^{8}$

Corporate competences are also defined in terms of the main collection of beliefs permitting identification and solution of certain problems, thus enabling the company to create alternatives for strategic growth and partially influence its environment. ${ }^{9}$ Under this interpretation, competences co-create the abilities to obtain, create and use both information and knowledge for efficient operation and effective growth with the additional factors influencing their occurrence conditioned by human beliefs, intuition and creativity.

However, in practice, it is assumed that competences rely on a set of phenomena of a behavioural and social character occurring within the company, which are of strategic importance for the company, particularly in the context of competitiveness, occurring as a result of experience gained from doing activities. ${ }^{10}$ They differ from other resources because they are harder to identify, they are of more routine nature and they are derived from various and numerous skills in the field of heterogenic activities and processes. ${ }^{11}$

\footnotetext{
${ }^{7}$ In the opinion of Peter Drucker, knowledge is the only economic resource determining competitive advantage. A. CHODYŃSKI, Wiedza i kompetencje ekologiczne w strategiach rozwoju przedsiębiorstw (Warsaw: Difin, 2007), 39.

${ }^{8}$ R. M. GRANT, "The Resource-based Theory of Competitive Advantage: Implications for Strategy Formulation," California Management Review 33, no. 3 (1991), 113-14.

${ }^{9}$ D. Lei, A. Hitt, and R. BetTis, "Dynamic Core Competencies Through Meta-Learning and Strategic Context," Journal of Management 22, no. 4 (1996): 550.

${ }^{10}$ J. B. BARNEY and E. J. ZAJĄC, "Competitive Organizational Behavior: Toward an Organizationally-Based Theory of Competitive Advantage," Strategic Management Journal 15 (1994): 6.

${ }^{11}$ RoKITA, Zarzadzanie strategiczne, 143.
} 
If the competences generated within a company are to play a major role in the shaping of its growth, they need to be regarded as valuable, that is, they need to be based on a strategic asset forming part of the internal operations of the company, so that the strategic value can be seen as a strength, a key element, an important characteristic or a key skill. ${ }^{12}$ The best foundation is created by a set of human competences and knowledge rather than a set of products and functions as only the first set has an intellectual character, being related to management systems and concerning the company as a whole. This stems from the fact that these competences are identified with knowledge cumulated as individual abilities that can be creatively used for the benefit of the whole company. ${ }^{13}$ Simultaneously, we need to remember that competences have to be managed affectively to be flexible and unique, relevant to customers' expectations, and they should concern those areas in which a given business can beat its competitors; also, it is best if competences are treated as a unique strategic asset. ${ }^{14}$ Another important factor is our attitude to competences, namely whether we take into consideration only the results that set the company apart as influencing its growth and being connected with its strategy (the individual level approach) or whether this approach is associated with the internal features of the company which distinguishes a given business from its competitors, for instance in light of research on organisational culture (organisation level approach).$^{15}$

The issue of corporate key competences in the context of the company's growth is also connected with the so-called model of innovative triangle. It relies on three inter-related components: strategic environmental orientation, network cooperation and the very competences involving motivation to act, knowledge of employees, possibilities of obtaining information from the environment, organisational practices and financial resources deemed necessary for the absorption of ecological innovations. ${ }^{16}$

In strategic terms, competences at the company level may be created by means of: quality and diversification of products, innovativeness, coopera-

${ }^{12}$ J. WySOCKI, "Kompetencje przedsiębiorstwa a innowacje," in Kreatywność - Innowacje Przedsiębiorczość, ed. P. Niedzielski, J. Guliński, and K. B. Matusiak (Szczecin: Wydawnictwo Naukowe Uniwersytetu Szczecińskiego, 2010), 73.

${ }^{13}$ K. OBŁó, Strategia organizacji (Warsaw: PWE, 1999), 86.

${ }^{14}$ M. BARTNICKI, Kompetencje przedsiębiorstwa. Od określenia kompetencji do zbudowania strategii (Warsaw: Placet, 2000), 18, 24-25.

${ }^{15}$ CHODYŃsKi, Wiedza i kompetencje, 80.

${ }^{16}$ K. van DiJKen eT AL., Adoption of Environmental Innovation (Dordrecht-Boston-London: Kluwer Academic Publisher, 1999), 47. 
tion with the environment, intellectual capital and responsibility of the business towards society. Therefore, each of those cases can involve ecological elements. ${ }^{17}$

The most general approach to competences is one that defines them as a collection of processes realised within a company, while emphasising their inter-functional character and their presence in all sections of an organisation. ${ }^{18}$ In this case we are dealing with basic competences conditioning the current market competition and dynamic competences which relate to the future customers and markets, enable the identification and satisfaction of future needs, and initiate innovative ideas allowing a given company to face modern competition and influence the company's growth. ${ }^{19}$ Nevertheless, the most commonly differentiated types of competences possessed by companies are the four listed here: ${ }^{20}$

- economic competences, involving issues related to the technology used, product quality, supplies, production capacity, production costs, marketing, distribution or service activities;

- managerial competences, occurring in the process of making decisions concerning finances, human resources, company organisation (inspections, communication, management);

- psychological competences, associated with the participants' abilities to assimilate rules and behaviours binding in the company's environment;

- (optionally) functional competences that include the know-how of employees, suppliers, managers, and cultural skills that enable others to perceive standards of work, quality, customer service, ability to change, etc.

As regards the usefulness of competences for the creation of the company's competitive advantage, they are divided in literature into two categories: the basic competences and so-called core competences or distinctive competences. Basic competences are connected with the basic areas of the company's activity and they do not permit the construction of a competitive

\footnotetext{
${ }^{17}$ G. GierszewsKa, "Kompetencje strategiczne na poziomie organizacji," in Zarzadzanie kompetencjami w organizacji, ed. E. Masłyk-Musiał (Warsaw: Wyższa Szkoła Menedżerska SIG, 2005), 29-39.

${ }^{18}$ D. J. Teece, G. Pisano, and A. Shuen, "Dynamic Capabilities and Strategic Management," Strategic Management Journal 18, no. 7 (1997): 509.

${ }^{19}$ B. GodZIsZEwski, Zasobowe uwarunkowania strategii przedsiębiorstwa (Toruń: Wydawnictwo UMK, 2001), 69.

${ }^{20}$ R. HALl, A Framework for Identifying the Intangible Sources of Sustainable Competitive Advantage, Competence-Based Strategic Management (Chichester: John Wiley \& Sons, 1997), 151, and STRATEGOR, Zarzadzanie firmq. Strategie, struktury, tendencje, tożsamość (Warsaw: PWE, 1999), 56.
} 
edge based on the creation of values important for customers, mostly due to their common character and lack of uniqueness. Basic competences include among others: research and development, design, technology, production, marketing, sales, customer service, managing finances, human resources and organisation.

On the other hand, core or distinctive competences are unique in their character, which means they are not typical for most businesses and thanks to that they are able to create their unique offer perceived by customers within the given area as attractive and competitive in relation to the offer of their competitors. This is why these competences are considered more desirable. Core competences are a complicated mix of resources, processes and abilities, and they include those features of a company which permit a consolidation and coordination of assets into a unique, harmonised whole. As a result, they create a set of abilities of special importance for the realisation of the intended strategy, which allows the company to gain competitive edge in the long run. However, the main elements of this strategy should not be constituted by products and markets but above all processes occurring within the company further transformed into certain strategic abilities and providing customers with new, satisfying values. Simultaneously, we need to remember that the mere ability to use core competences properly becomes their integral element.

Besides the ability to survive, develop and generate additional value, core competences constitute but one factor conditioning the company's success shaped on the basis of knowledge possessed by that company. The core competences differ from the basic competences also in their much greater ability to win access to an important market and guarantee a measurable contribution to benefits visible to customers. They permit a reduction of expenditure, they can prevent competitors from copying and facilitate the management of the strategic architecture. Moreover, they refer to the potential abilities to act resulting from continuous organisational learning, which is crucial, among others, for the assurance of appropriate level of environmental protection and safety. Also, continuous, in-house training creates an opportunity to create and develop core competences but on condition that the learning process will involve both the improvement of individual skills and their integration as well as their application in the company's business operation. 


\section{THE ESSENCE OF ECOLOGICAL COMPETENCES}

Any competences related to the management of change, organisational education, knowledge management (KM), entrepreneurship, development of social capital, development of technological and product innovations or the possibility to use opportunities resulting from globalisation are considered to be crucial for today's companies. However, when faced with advancing ecologisation of business activities, we should add to the competences listed above ecological ones, since these competences may refer to ecology (as argued by Andrzej Chodyński), which currently is a very important aspect of organisational structure. It influences competences perceived as an external factor. ${ }^{21}$ From the strategic point of view, the organisational structure together with reputation, knowledge and skills of both the company and the employees jointly create those intangible assets which are beginning to be perceived as the most valuable and desirable because the employees possess them and they condition the company's market success..$^{22}$ At the same time, these assets build intellectual or non-financial capital. This demonstrates the invisible gap between the market value and the accounting value of a company, and this can be considered as a liability rather than an asset. ${ }^{23}$ Consequently, this very capital should constitute a foundation for the development of ecological competences using KM. ${ }^{24}$ As a result, ecological competences allow ecological resources to be managed more effectively and enable recognition of interactions between various elements of the environment and minimisation of ecological risks. ${ }^{25}$

The quoted author believes that the theoretical achievements in the area of ecological competences point to considerable environmental capabilities inherent in resources, organisational learning within an organisation or KM theories, which should continue to be explored for further development of these competences. ${ }^{26}$ Simultaneously, the same author remarks that, importantly, ecological competences may be manifested in abilities relating to the improvement of ecological security, which makes it easier to determine

${ }^{21}$ A. CHODYŃSKI, "Kompetencje ekologiczne a rozwój przedsiębiorstwa," Przegląd Organizacji, no. 7-8 (2006): 44-46.

${ }^{22}$ U. KŁosIEWICZ and B. SŁOMIŃSKA, "Niematerialne zasoby firmy źródłem sukcesu na rynku," Marketing i Rynek, no. 10 (1996): 17.

${ }^{23}$ L. EDVINSSON and M. S. MALONE, Kapitat intelektualny (Warsaw: PWN, 2001), 39-40.

${ }^{24}$ CHODYŃSKI, Wiedza i kompetencje, 43.

${ }^{25}$ K. ZIMNIEWICZ, Współczesne koncepcje i metody zarządzania (Warsaw: PWE, 1999), 178.

${ }^{26}$ CHODYŃSKI, Bezpieczeństwo ekologiczne, 195. 
optimal living conditions in the environment and develop methods of preventing biological, chemical and physical pollution. Other components of these competences may be quality, company innovativeness and ecological marketing, where:

- quality is the competence enabling the creation of value added by distinguishing a product, process or enterprise on the market,

- innovativeness is the competence allowing the creation and introduction of innovations as part of value development for the sake of all stakeholders,

- marketing is the competence that provides the possibility of developing an ecological product and creating demand for it among potential customers. ${ }^{27}$

As mentioned above, competences are based mostly on people's knowledge and manifested in their specific abilities, which in the context of ecology requires the knowledge of certain ecological issues. ${ }^{28}$ Gaining such knowledge is typically the result of learning and teaching, jointly understood as education. ${ }^{29}$ In consequence, proper ecological education that enables knowledge and abilities to be gained in regard to the use of non-renewable resources, sustainable growth, recycling, natural medicine or ecotourism becomes an issue of paramount importance. ${ }^{30}$ At company level, ecological knowledge (i.e., information and abilities connected with processes occurring in ecosystems, the knowledge of ecosystem balance mechanisms, the knowledge of relationships among various forms of business activities in the natural environment, the knowledge of pollution types and methods of prevention) may be gained from the contact with other organisations, local authorities or from systems that provide data on the condition of the environment. ${ }^{31}$ Simultaneously, effective management of ecological knowledge, constituting a component of ecological competences creates a platform for companies to make a decision to become ecologically involved. ${ }^{32}$ Thus, ecological education

\footnotetext{
${ }^{27}$ CHODYŃSKI, Wiedza i kompetencje, 115, 128-129, 169.

${ }^{28}$ CHODYŃsKi, Bezpieczeństwo ekologiczne, 199.

${ }^{29}$ M. MALEWSKI, Od nauczania do uczenia się. O paradygmatycznej zmianie $w$ andragogice (Wrocław: Wydawnictwo Naukowe Dolnośląskiej Szkoły Wyższej, 2010), 46.

${ }^{30}$ J. ZARĘBSKA, "Znakowanie ekologiczne towarów a świadomość ekologiczna młodzieży," General and Professional Education, no. 4 (2014): 88.

${ }^{31}$ P. SKowron, "Kreowanie wiedzy ekologicznej w przedsiębiorstwie," in Edukacja dla zrównoważonego rozwoju, vol. 2, Edukacja dla ładu ekonomicznego, ed. T. Borys and B. Poskrobko (Białystok-Wrocław: Ekonomia i Środowisko, 2010), 263-64.

32 O. Seroka-StolKa, T. NitKiewicz, and A. BrzozowsKa, "Rola wiedzy ekologicznej w proaktywnym rozwoju przedsiębiorstwa," in Przedsiębiorstwo jako organizacja uczaca się, ed.
} 
plays a crucial role in building societal respect for nature as it builds and ingrains ecological awareness in society. In relation to companies, it also shapes green attitudes of both managers and employees, provides engineers, various technicians and managers with environmental knowledge, as well as contributing to the education of specialists in environmental protection. ${ }^{33}$ Thus, ecological competences created on the basis of ecological knowledge constitute the best starting point for the construction of proper competitive position of a business, especially if they rely on ecological security stabilised by the implementation of concepts of ecological growth. ${ }^{34}$

Similarly to any other spheres of company operations, including the environmental sphere, the most valuable sources of ideas are the core competences mentioned above, which are the most efficient at supporting the "birth" and realisation of pro-environmental activities. Therefore, companies interested in environmental protection should strive not so much to develop basic competences as core ecological competences which will translate into long a lasting competitive advantage. Yet the crucial condition to be fulfilled is that the source of this advantage lies in performing the necessary activities, but this requires proper tangible and intangible assets expressed mainly in human resources and know-how and ultimately sets out the company's development strategy. ${ }^{35}$ When building ecological competences, certain skills of both the management staff and employees prove extremely useful, because they create a specific set of competences of an organisation presented in Table 1 below.

Table 1. A set of skills required to develop ecological competences

\begin{tabular}{|l|}
\hline \multicolumn{1}{|c|}{ Range of skills useful for the development of ecological competences } \\
\hline Identify significant environmental aspects \\
\hline Choose ecological priorities \\
\hline Determine the ecological profile \\
\hline Apply legal regulations and their interpretations \\
\hline Use checklists and so-called good management practices \\
\hline
\end{tabular}

B. Olszewska, M. Czarnecki, and E. Piwoni-Krzeszowska (Wrocław: Wydawnictwo Uniwersytetu Ekonomicznego we Wrocławiu, 2013), 103-4.

${ }^{33}$ Gospodarka a środowisko i ekologia, ed. K. Małachowski (Warsaw: CeDeWu, 2007), 35.

${ }^{34}$ A. CHODYŃSKI, Bezpieczeństwo ekologiczne, 194-95.

${ }^{35}$ M. E. Porter, "What is strategy," Harvard Business Review 74, no. 6 (1996): 68. 


\begin{tabular}{|l|}
\hline Identify and use the ecological lifecycle of a product \\
\hline Identify critical ecological parameters \\
\hline Minimise ecological risk \\
\hline Use a proactive approach to risk and safeguard against ecological risks \\
\hline Identify ecological conditions and follow them \\
\hline Define the company's value for "ecological reasons" \\
\hline Project an ecological image and establish corporate PR \\
\hline Cooperate with green organisations \\
\hline Use external financing for ecological initiatives \\
\hline Continue learning \\
\hline Benefit from own experience and the experience of other companies \\
\hline
\end{tabular}

Source: own material, based on A. Kubasik, "Spheres of Creation of Company's Ecological Competences,” Economic Studies of Economic University in Katowice, no. 37 (2006): 160.

Paraphrasing the statement of C. K. Prahalad and Gary Hamela concerning environmental needs, we may assume that the core ecological competences of a company include above all the management's abilities to create technologies and develop such production skills that will guarantee quick adjustment to the ever changing conditions as well as the team's knowledge related to the integration of numerous technologies and coordination of various production skills, while simultaneously keeping in mind the respect for and protection of the environment. ${ }^{36}$ These authors even claim that the value of ecological competences may be assessed in light of definite features which are linked with environment-related abilities.

The most important aspects of the core competences that deserve special attention in the context of business operations include: $:^{37}$

- reliance on knowledge

- rarity and exceptional character

- difficult to imitate (e.g., through benchmarking)

- hardly substitutable (e.g. through outsourcing)

${ }^{36}$ C. K. Prahalad and G. Hamel, "The Core Competence of the Corporation," Harvard Business Review (May-June 1990): 81-82.

${ }^{37} \mathrm{~K}$. MoszKOwICZ, "Zasobowy model formułowania strategii przedsiębiorstwa a procesy innowacyjne," in Zarzadzanie strategiczne w praktyce i teorii. Prace naukowe 1025 (Wrocław: Wydawnictwo AE im. O. Langego, 2004), 230, M. J. STANKIEwICZ, Konkurencyjność przedsiębiorstw. Budowanie konkurencyjności przedsiębiorstwa w warunkach globalizacji (Toruń: „Dom Organizatora”, 2002), 212. 
- limited possibilities regarding purchase and sales

- their perceived value compared to the costs incurred to develop them

- ability to create new ecological products and markets

- durability in contrast to typical tangible assets and skills as the former are not exhausted but over time they multiply and may increasingly positively impact the company's competitiveness.

The creation of added value and customer value through the development of new product functionalities or completely new products and spheres of activity is considered to be the basic purpose of core competences. Owing to that, companies need to focus on the development of core competences because the latter determine the effectiveness of activities aimed at development. To a certain extent, Peter F. Drucker believes this is important as he believes that nowadays value is created by innovations and productivity, but knowledge and competences are essential for this process. ${ }^{38}$ Thus, if we assume that pro-environmental activities affect the generation of a greater added value or possibly higher incomes, or reduce expenditures through an efficient implementation of new ideas, organisational changes, a wider product range or new processes, we can speak of the company's proper application of its core ecological competences.

The added value generated by the company stems from the difference between product costs and services and their sales price, added to the value of those products and services. ${ }^{39}$ In the measurable approach, the latter means that the added value is created by the net profit, income tax, depreciation, bank loan interest, and salaries with overheads. Naturally, the genuine added value is not solely the result of transformation of resources and materials but rather the effect of developing new products and services as well as their integration. This value is connected not only with the productivity and efficiency of operations of a company but also with the company's ability to gain benefits resulting from standing out in terms of production capacity, quality, innovation, and the current pro-environmental activities.

The situation looks similar in the case of creating value in use for customers, which happens also in processes exploiting core competences to create a greater added value. ${ }^{40}$ This fact is confirmed by companies that successfully operate in the market which treats the satisfaction of the customers'

${ }^{38}$ P. F. DRUCKER, Spoleczeństwo prokapitalistyczne (Warsaw: PWN, 1999), 14; BARNEY and ZAJAc, Competitive Organizational Behavior, 6.

${ }^{39}$ Rokita, Zarzadzanie strategiczne, 184-85.

${ }^{40}$ UrbanOWSKA-SOJKIn, BANASZYK, and WITCZAK, Zarzqdzanie strategiczne, 269. 
expectations and needs as the superior objective. Thus, the creation of value in use for the customer provides information on the way in which to use the resources and core competences at hand and also indicates the extent to which a particular company is customer-oriented and focused on the maximisation of customers' satisfaction. The latter is achieved as a result of increasing own values by transforming the production factors into various types of goods and services which will be environmentally friendly.

Inside companies, the creation of values is performed at higher levels of management and within all functional areas, while the effectiveness of this process is achieved through appropriate management. ${ }^{41}$ Such management is useful in the process of company improvement, which nowadays requires the creation of ever newer core ecological competences and subsequently the creation of new abilities, processes and assets determining the achievement of competitive advantage in the environmental scope. For instance, high quality and low price may result from, among others, an innovative technology, effective management of quality and control or from green marketing strategy all constituting the result of pro-environmental activities based on competences. However, effective management of the company's value requires the knowledge of the basic sources of competitive edge and of core competences differentiating the company from others, including the methods to create them.

\section{CONCLUSION}

In conclusion, we need to emphasise that the development of core ecological competences is a long but necessary process if a company wishes to develop and function as a market leader. That is why it is sometimes worthwhile to take advantage of solutions serving to develop such competences, for instance: determining ecological standards and monitoring pollution limits, accepting market rules in terms of environmental protection, establishing cooperation with government agencies, implementing environmental management or reporting systems. ${ }^{42}$ As rightly pointed out by Chodyński, the creation of ecological competences - similarly to the creation of ecological intellectual capital or creation of green innovations - should be justified on

${ }^{41}$ The concept of company value management has been created (Value-Based Management).

${ }^{42}$ See A. Prakash and K. Kollman, "Policy modes, firms and the natural environment," Business Strategy and the Environment 13, no. 2 (2004): 107-27. 
the assumption that the company's growth is to have a strictly proactive character and result from the endorsement of environmental responsibility principles. $^{43}$

Core ecological competences, which are developed using a combination of mutually complementary and reinforcing skills and the environmental knowledge possessed by both managers and employees, allow companies to implement their production processes without threatening the natural environment and to create products of a high ecological standard. As a result of this, they determine the impact of the ecological factor on the shape of the company's development strategy and on its business model. Moreover, they contribute to the increased value of the company manifested by its strong competitive position. ${ }^{44}$ The ability to apply the requirements of ecological quality at every stage of the company's development strategy also constitutes an important element of ecological competences, from the formulation of such a strategy to the implementation and strategic control, where this quality provides a system of product quality descriptions and manufacturing processes in which ecological parameters and factors play a key role. ${ }^{45}$

For contemporary companies, the crucial protective activity in the face of the dynamically changing environment is therefore to determine the objective of business activities and concentrate on the creation of core ecological competences. Only these using those competences can one realise this objective out of consideration for both environmental and sociological aspects, which constitute elements of sustainable growth. This stems from the fact that the company's success largely results from the company's skills to identify core ecological competences, which will be necessary in the future to determine the chances of creating such competences and their practical application.

\footnotetext{
${ }^{43}$ For more on proactive growth, see A. CHODYŃSKI, Odpowiedzialność ekologiczna w proaktywnym rozwoju przedsiębiorstw (Kraków: Krakowskie Towarzystwo Edukacyjne - Oficyna Wydawnicza AFM, 2011), 205.

${ }^{44}$ CHODYŃSKI, Bezpieczeństwo ekologiczne, 199.

${ }^{45}$ Ecological competences permit even the creation of a strategy of ecological quality combined with the elements of quality and ecology, A. CHODYŃSKI, Zarzadzanie rozwojem firmy. Strategia jakości ekologicznej (Sosnowiec: Wydawnictwo Wyższej Szkoły Zarządzania i Marketingu „Humanitas”, 2002), 74-75, and KUBASIK, Obszary kreowania, 159-60.
} 


\section{BIBLIOGRAPHY}

BARNEY, Jay B., and Edward J. ZAJĄC. "Competitive Organizational Behavior: Toward an Organizationally-Based Theory of Competitive Advantage." Strategic Management Journal 15 (1994): 5-9.

BARNICKI, Mariusz. Kompetencje przedsiębiorstwa. Od określenia kompetencji do zbudowania strategii. Warsaw: Placet, 2000.

CHODYŃSKI, Andrzej. "Bezpieczeństwo ekologiczne, kompetencje a zaufanie międzyorganizacyjne. Aspekty strategiczne.” In Społeczne i ekologiczne aspekty zarzadzania, edited by Andrzej Chodyński, 193-200. Kraków: Krakowskie Towarzystwo Edukacyjne - Oficyna Wydawnicza AFM, 2007.

ChOdyŃski, Andrzej. “Kompetencje ekologiczne a rozwój przedsiębiorstwa.” Przegląd Organizacji, no. 7-8 (2006).

CHODYŃSKI, Andrzej. Odpowiedzialność ekologiczna w proaktywnym rozwoju przedsiębiorstw. Kraków: Krakowskie Towarzystwo Edukacyjne - Oficyna Wydawnicza AFM, 2011.

CHODYŃSKI, Andrzej. Wiedza i kompetencje ekologiczne w strategiach rozwoju przedsiębiorstw. Warsaw: Difin, 2007.

ChodyŃski, Andrzej. Zarządzanie rozwojem firmy. Strategia jakości ekologicznej. Sosnowiec: Wydawnictwo Wyższej Szkoły Zarządzania i Marketingu „Humanitas”, 2002.

De Wit, Bob, and Ron Meyer. Strategy: Process, Content, Context, An International Perspective. London: International Thomson Business Press, 1998.

DRUCKER, Peter F. Spoleczeństwo prokapitalistyczne. Warsaw: PWN, 1999.

Edvinsson, Leif, and Michael Malone. Kapitat intelektualny. Warsaw: PWN, 2001.

FABIAŃSKA, Krystyna, and Jerzy RoKITA. Zarzadzanie. Strategia tworzenia przewagi konkurencyjnej przedsiębiorstwa. Katowice: Petex, 1995.

GIERSZEWSKA, Grażyna. "Kompetencje strategiczne na poziomie organizacji.” In Zarzadzanie kompetencjami w organizacji, edited by Ewa Masłyk-Musiał, 29-39. Warsaw: Wyższa Szkoła Menedżerska SIG, 2005.

GODZISZEWSKI, Bohdan. Zasobowe uwarunkowania strategii przedsiębiorstwa. Toruń: Wydawnictwo UMK, 2001.

Gospodarka a środowisko i ekologia. Edited by Krzysztof Małachowski. Warsaw: CeDeWu, 2007.

GRANT, Robert M. "The Resource-Based Theory of Competitive Advantage: Implications for Strategy Formulation," California Management Review 33, no. 3 (1991).

HALL, Richard. A Framework for Identifying the Intangible Sources of Sustainable Competitive Advantage, Competence-Based Strategic Management. Chichester: John Wiley \& Sons, 1997.

Hamel Gary, and C. K. Prahalad, Przewaga konkurencyjna jutra. Strategie przejmowania kontroli nad branża i tworzenia rynków przyszłości. Warsaw: Business Press, 1999.

HiLl, Charles W., and Gareth R. Jones. Strategic Management Theory. An Integrated Approach. Boston: Houghton Mifflin, 1992.

KŁosiewicz, Urszula, and Bożena SŁomiŃSKA. "Niematerialne zasoby firmy źródłem sukcesu na rynku.” Marketing i Rynek, no. 10 (1996).

KUBASIK, Andrzej. "Obszary kreowania kompetencji ekologicznych przedsiębiorstwa." Studia Ekonomiczne Akademii Ekonomicznej w Katowicach, no. 37 (2006): 157-72. 
LeI, David, Michael A. Hitt, and Richard BetTis. "Dynamic Core Competencies Through MetaLearning and Strategic Context." Journal of Management 22, no. 4 (1996): 549-69.

MALEWSKI, Mieczysław. Od nauczania do uczenia się. O paradygmatycznej zmianie $w$ andragogice. Wrocław: Wydawnictwo Naukowe Dolnośląskiej Szkoły Wyższej, 2010.

Moszkowicz, Krystyna. "Zasobowy model formułowania strategii przedsiębiorstwa a procesy innowacyjne." In Zarzadzanie strategiczne w praktyce $i$ teorii. Prace naukowe 1025, 230. Wrocław: Wydawnictwo AE im. O. Langego, 2004.

OвŁóJ, Krzysztof. Strategia organizacji. Warsaw: PWE, 1999.

PENC, Józef. Zarządzanie dla przyszłości. Twórcze kierowanie firmą. Kraków: Wydawnictwo Profesjonalnej Szkoły Biznesu, 1998.

Penrose, Edith. The Theory of Growth of the Firm, Resources, Firms and strategies. Oxford: Oxford University Press, 1997.

PORTER, Michael E. "What is strategy.” Harvard Business Review 74, no. 6 (1996).

Prahalad, C. K., and Gary Hamel. "The Core Competence of the Corporation." Harvard Business Review" (May-June 1990).

PraKash, Aseem, and Kelly Kollman. "Policy Modes, Firms and the Natural Environment." Business Strategy and the Environment 13, no. 2 (2004): 107-28.

RAKOwSKA, Anna. "Przewaga konkurencyjna i kompetencje polskich przedsiębiorstw w kontekście wymagań stawianych nowoczesnym organizacjom.” Organizacja i Zarządanie, no. 4 (2008): 7-20.

RoKITA, Jerzy. Zarzadzanie strategiczne. Tworzenie i utrzymanie przewagi konkurencyjnej. Warsaw: PWE, 2005.

Senge, Peter M. The Fifth Discipline, the Art and Practice of the Learning Organization. New York: Doubleday Currency, 1990.

Seroka-Stolka, Oksana, Tomasz Nitkiewicz, and Anna Brzozowska. "Rola wiedzy ekologicznej w proaktywnym rozwoju przedsiębiorstwa." In Przedsiębiorstwo jako organizacja uczaca się, edited by Barbara Olszewska, Maciej Czarnecki, and Estera Piwoni-Krzeszowska, 103-12. Wrocław: Wydawnictwo Uniwersytetu Ekonomicznego we Wrocławiu, 2013.

SKowron, Paweł. "Kreowanie wiedzy ekologicznej w przedsiębiorstwie." In Edukacja dla zrównoważonego rozwoju, vol. 2, Edukacja dla ładu ekonomicznego, edited by Tadeusz Borys and Bazyli Poskrobko, 263-82. Białystok-Wrocław: Ekonomia i Środowisko, 2010.

STANKIEWICZ, Marek J. Konkurencyjność przedsiębiorstw. Budowanie konkurencyjności przedsiębiorstwa w warunkach globalizacji. Toruń: „Dom Organizatora”, 2002.

STRATEGOR. Zarzadzanie firma. Strategie, struktury, tendencje, tożsamość. Warsaw: PWE, 1999.

Teece, David J., Gary Pisano, and Amy Shuen. "Dynamic Capabilities and Strategic Management.” Strategic Management Journal 18, no. 7 (1997): 509-33.

URBANOWSKA-SOJKIN, Elżbieta, Piotr BANASZYK, and Hubert WITCZAK. Zarzadzanie strategiczne przedsiębiorstwem. Warsaw: PWE, 2004.

Van Dijken, Koos, Yvonne M. Prince, T.J. Wolters., Marco Frey, Giuliano Mussati, Paul KAlfF, Ole HANSEn, ET AL. Adoption of Environmental Innovations: The Dynamics of the Innovation as Interplay between ... Dordrecht: Kluwer Academic Publishers, 1999.

WYsocki, Jacek. "Kompetencje przedsiębiorstwa a innowacje.” Kreatywność - Innowacje Przedsiębiorczość, edited by Piotr Niedzielski, Jacek Guliński, and Krzysztof B. Matusiak, 71-82. Szczecin: Wydawnictwo Naukowe Uniwersytetu Szczecińskiego, 2010. 
ZARĘBSKA, Joanna. "Znakowanie ekologiczne towarów a świadomość ekologiczna młodzieży." General and Professional Education, no. 4 (2014): 86-94.

ZIMNIEWICZ, Kazimierz. Wspótczesne koncepcje i metody zarządzania. Warsaw: PWE, 1999.

\title{
CREATION OF ECOLOGICAL COMPETENCES WITHIN A COMPANY - A THEORETICAL APPROACH
}

\begin{abstract}
Summary
Ecological competences, similarly to ecological products, technologies and innovations have played an increasingly important role in the development of the company, determining both the increase in company's value and its market success for a longer period of time. Ecological knowledge and competences possessed by companies may effectively prevent the occurrence of environmental issues and properly shape environmental security, which is associated with the elimination of ecological threats not only for individual companies, but also for the entire global economy. Ecological competences, which are created as a combination of mutually complementary and strengthening skills and environmental knowledge possessed by both managers and employees, allow the company to realise its production process without threat to environment and to create products of high ecological standards. As a consequence, these competences become a key element of the company's success, which is crucial for gaining a competitive advantage, so it is worth looking into this issue.
\end{abstract}

Key words: management; company; competences; ecological competences.

\section{TWORZENIE KOMPETENCJI EKOLOGICZNYCH W PRZEDSIEBIORSTWIE - UJĘCIE TWORETYCZNE}

\section{Streszczenie}

Kompetencje ekologiczne, podobnie jak produkty, technologie czy innowacje ekologiczne, odgrywają coraz ważniejszą rolę w rozwoju przedsiębiorstwa, decydując m.in. o wzroście jego wartości i szeroko rozumianym sukcesie rynkowym. Posiadana przez przedsiębiorstwa wiedza i kompetencje ekologiczne pomagają bowiem skutecznie zapobiegać problemom środowiska naturalnego i właściwie kształtować jego bezpieczeństwo, które jest kojarzone z eliminacją zagrożeń ekologicznych nie tylko w przypadku pojedynczych przedsiębiorstw, ale także w skali całej gospodarki globalnej. Kompetencje ekologiczne, które powstają jako kombinacja wzajemnie uzupełniających się i wzmacniających umiejętności oraz wiedzy środowiskowej posiadanej przez menedżerów i pracowników, pozwalają przedsiębiorstwu realizować bezpieczne dla środowiska procesy produkcyjne i tworzyć produkty o wysokich standardach ekologicznych. W konsekwencji kompetencje te mogą stanowić kluczowy element sukcesu przedsiębiorstwa, istotnie decydujący o uzyskaniu przewagi konkurencyjnej, dlatego warto przyjrzeć się bliżej temu zagadnieniu.

Słowa kluczowe: zarządzanie; przedsiębiorstwo; kompetencje; kompetencje ekologiczne. 